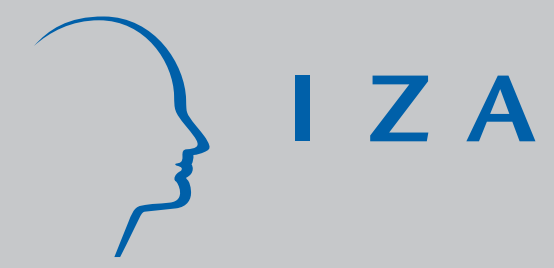

IZADP No. 3415

Macroeconomic Effects of Ownership Structure in OECD Countries

Donatella Gatti

March 2008 


\title{
Macroeconomic Effects of Ownership Structure in OECD Countries
}

\author{
Donatella Gatti \\ CEPN-Paris 13, Paris School of Economics, \\ CEPREMAP and IZA
}

Discussion Paper No. 3415

March 2008

\author{
IZA \\ P.O. Box 7240 \\ 53072 Bonn \\ Germany \\ Phone: +49-228-3894-0 \\ Fax: +49-228-3894-180 \\ E-mail: iza@iza.org
}

\begin{abstract}
Any opinions expressed here are those of the author(s) and not those of IZA. Research published in this series may include views on policy, but the institute itself takes no institutional policy positions.

The Institute for the Study of Labor (IZA) in Bonn is a local and virtual international research center and a place of communication between science, politics and business. IZA is an independent nonprofit organization supported by Deutsche Post World Net. The center is associated with the University of Bonn and offers a stimulating research environment through its international network, workshops and conferences, data service, project support, research visits and doctoral program. IZA engages in (i) original and internationally competitive research in all fields of labor economics, (ii) development of policy concepts, and (iii) dissemination of research results and concepts to the interested public.
\end{abstract}

IZA Discussion Papers often represent preliminary work and are circulated to encourage discussion. Citation of such a paper should account for its provisional character. A revised version may be available directly from the author. 
IZA Discussion Paper No. 3415

March 2008

\section{ABSTRACT \\ Macroeconomic Effects of Ownership Structure in OECD Countries*}

The paper investigates the impact of ownership concentration on GDP growth, for a sample of 18 OECD countries over the period 1980 to 2004. The econometric analysis shows that more concentrated ownership can speed up growth, for countries approaching the technological frontier, provided that labour market regulation is sufficiently tight. In the absence of employment regulation, the logic of financial markets discipline applies and dispersed ownership appears as more favorable for growth. Based on econometric results, impact coefficients are calculated allowing to evaluate the growth points gained/lost following a given change in ownership concentration. This exercise reveals that a reform in the domain of ownership structure can yield sizeable effects in terms of growth. Importantly, these effects are unequally distributed across countries: Anglo-Saxon countries would take more advantage of deregulation (i.e. increased dispersion of ownership in a context of deregulated labour markets) while continental European countries would benefit more from increased concentration of ownership in a context of reinforced labour regulation.

JEL Classification: $\quad$ O43, O57, G32, K31

Keywords: ownership concentration, labour market regulation, growth, developed countries

Corresponding author:

Donatella Gatti

CEPREMAP

142 rue de Chevaleret

75013 Paris

France

E-mail: donatella.gatti@cepremap.cnrs.fr

\footnotetext{
* The author is indebted to Dominique Plihon, Antoine Rebérioux, Jean-Philippe Touffut, Anne-Gaël Vaubourg and Christophe Clerc for extremely helpful discussions on the topic.
} 


\section{Introduction}

This paper shades light on the macroeconomic consequences of firms' ownership structures. The importance of ownership structure with respect to macroeconomic performance has been acknowledged since the influential contributions by La Porta et al. [1998] and [1999] as well as, more recently, Djankov et al. [2006]. These authors investigate the effects of ownership in large sample of developing/developed countries and underline the possible emergence of perverse political economy mechanisms leading powerful owners to ensure their interest by countering (at the political level) the financial development of a country. Hence, concentrated ownership would lead to underdevelopment traps with immature financial markets and weak growth (see also Morck, Wolfenzon and Yeung, 2005).

This result relies on a standard distinction made within the corporate governance literature ${ }^{1}$ between two alternative models of governance: the "insider" model (based on stable concentrated ownership) and the "outsider" model - based on dispersed ownership. Part of the literature identifies the Anglo-Saxon (outsider) corporate governance model as the most performing one, in particular during the last decade. However, some authors insist on the fact that each model of corporate governance has its own strengths and weaknesses (Shleifer and Vishny 1997).

In fact, recent contributions in law and economics suggest that the impact of ownership structure indeed depends on "contexts". In particular, markets' regulation provides a crucial environment to assess the effects of different structures of ownership. More specifically, a link would exist between ownership structure and employment relations because stable, concentrated ownership contributes, together with labour market regulation, to foster long-term partnerships with crucial categories of stake-holders (Blair, 2003; Deakin et al., 2002; Rebérioux, 2002). A similar argument is developed within the approach in terms of "varieties of capitalism". This literature suggests that corporate governance models are embedded into larger institutional frameworks (Aguilera and Jackson, 2003). Stable institutional arrangements contribute to foster cooperation among actors within corporations (shareholders as well as stakeholders): cooperation allows to achieve

\footnotetext{
${ }^{1}$ Becht and Mayer, 2001; Faccio and Lang, 2002; Gugler et al., 2004; Shleifer and Vishny, 1997.
} 
better economic performance, by favouring specific investments by/on stakeholders as well as long-term projects by corporate managers (Deakin et al., 2002; Hall and Soskice, 2001).

In a similar vein, contributions in political economy and political economics indicate that ownership and markets regulations should be seen as joint results of a political process. Pagano and Volpin (2005) highlight two possible political equilibriums emerging out of a political compromise between employees and managers: a "corporatist" equilibrium achieved by exchanging larger independence for managers against stronger employment protection, and an Anglo-Saxon equilibrium characterized by strong shareholders protection and weak job security. Baker and Rueda [2007] describe "the situation prevailing in the golden age of social democracy" as the result of a de facto coalition between "insider capital" and "insider labor": this coalition allows insider actors to extract rents from outsider actors, and redistribute the benefit of these rents among insiders. Hence, the insider model of corporate governance would require not only concentrated ownership, but also stable labour relations. On the contrary, the outsider model would be based on more dispersed ownership and flexible labour relations.

Turning to the empirical evidence, a growing stream of literature investigates the macroeconomic impact of markets' regulation within OECD countries. This literature points to the need for deregulation on product, labour and financial markets in order to speed up growth, particularly when a country is approaching the "technological frontier" (Aghion, 2006; Conway et al., 2006; Nicoletti and Scarpetta, 2003; Acemoglu et al., 2007). Acemoglu et al. [2007] suggest that increased regulation more "effectively" reduces incentives to innovate in countries/sectors close to the technological frontier. However, a few recent contributions cast some doubt on the robustness of these results (Amable, Demmou and Ladezma, 2007). Unfortunately, all studies above overlook the role of ownership structure.

This paper aims to fill the gap and empirically assess the joint effects of ownership structure and labour markets' regulation on GDP per employee growth, for a sample of 18 OECD countries, over the period 1980-2004. In the next section, I explore the main theoretical channels through which ownership concentration can influence growth, and also present some descriptive evidence about the linkages between ownership concentration, labour market regulation and GDP per employee growth. In section 3, the econo- 
metric framework is proposed and evidence is presented by testing a growth equation on macroeconomic data for 18 OECD countries. In section 4 , the estimated model is used to calculate impact coefficients for ownership concentration on growth; results from simulations are discussed providing some hints on the effects of different scenarios of structural reforms. Section 5 briefly concludes.

\section{Ownership structure: a macroeconomic approach}

In this section, I present the main theoretical channels through which ownership structure may influence GDP per employee growth. I subsequently turn to the descriptive evidence concerning the effects of ownership structure, by exploiting a dataset of 18 OECD countries over the period 1980-2004.

\section{1 theoretical channels}

In their influential contributions, La Porta et al. [1998] and [1999] as well as Djankov et al. [2006] develop a framework to assess the impact of ownership structure on growth, based on the logic of financial markets development and discipline. The authors adhere, in particular, to the idea that a single "best solution" exists to the agency problem between managers and owners: a system of dispersed ownership (linked to highly developed financial markets) coupled with strong legal protection of shareholders. The reasons why this system would favor growth are two-fold. First, while owners are prevented to exert strong direct control because they own small shares of public companies, managers are exposed to exit and/or takeover threats; this market discipline ensures that managers will "do the right thing" to maximize the company value. Second, dispersed ownership prevent owners to become too powerful and divert wealth according to their own private interest; this allows to avoid perverse political economy scenarios, such as powerful elites countering the financial development of a country, at the political level. To sum up, this situation is expected to yield an efficient allocation of investments, and positive effects on growth.

A few critics can be raised against these conclusions. First of all, the effects of concentrated ownership are probably very different according to a country level of development. If one focuses on developed countries, it appears that the structure of ownership primarily has to "fit" production 
needs: in specific sectors, concentrated ownership may well be beneficial to production, by favoring cooperation, economic stability and specific investments (Carlin and Mayer, 2003; Hall and Soskice, 2001). Moreover, tight financial markets discipline also yields a bias in strategic investments, by leading to excessive short-term maximization of firms' market value (Blair, 2003).

The literature has explored possible alternatives to financial markets discipline and "shareholders models". In particular, scholars have recently turned to the so called "stakeholders model" within which stakeholders, and in particular employees, are seen as actors making specific investments and thus improving their company's capital stock and value. However, for specific investment to emerge, effective incentives must be in place: stable partnerships appear as a possible device to protect investors. Stable partnerships can be enforced through law and regulation, as well as through a greater concentration of ownership (Blair, 2003; Deakin et al., 2002). Hence, ownership concentration and markets regulation both appear to be ingredients of a stakeholder model of governance, thus favouring growth through investments in firm specific assets such as human and physical capital.

A related argument is explored by Kharroubi [2006] who studies the effects of markets regulation on technology and growth. The model shows that markets regulation pushes firms to invest in more productive technologies through a two-fold incentive mechanism: first, upgrading capital allows firms to make their "almost-fixed" labour stock more efficient; second, whenever technological investments are successful, they generate higher cash-flows allowing to ease liquidity constraints. Hence, markets regulation may generate positive macroeconomic effects in terms of growth.

Finally, ownership concentration and markets regulation are frequently associated with the emergence of economic and/or political "elites". It should be noted that, in the presence of externalities and market failures, elites can effectively improve coordination across economic actors and favor industrial modernization (Amable and Hancké, 2001). This mechanism bears important consequences for innovation and growth: business coordination (through elites, connected ownership and networks) allows firms to better account for externalities stemming from education and innovation activities (Gatti, 2000). Hence, corporations embedded in coordinated environments are likely to engage in education and research investments bearing 
important externalities, that would otherwise be overlooked by private actors.

The theoretical arguments briefly reviewed above suggest that different structures of ownership may yield contrasted effects on growth. In particular, the "context" (i.e. markets regulation) plays a crucial role: in the presence of tightly regulated markets, ownership concentration creates incentives for corporate stakeholders to bear substantive efforts in specific investments; on the other hand, deregulated markets and dispersed ownership enforce market discipline as a device preventing costly inefficiencies.

The issue is therefore primarily empirical. I now turn to present the descriptive empirical evidence drawn on a sample of OECD countries over the period 1980 to 2004.

\section{2 what do data suggest?}

The empirical analysis relies on a sample of 18 OECD countries ${ }^{2}$ over the period 1980 to 2004. The sample includes a number of variables capturing the institutional, regulatory, political and macroeconomic features of all countries. These variables are presented and commented in the Appendix. In this Section, I will focus on three main variables in my analysis: macroeconomic performance, ownership structure and labour market regulation.

In order to capture macroeconomic performance, I rely on data about GDP per employee (both in level and in growth rate); these data are drawn from OECD as well as Penn World Table.

Concerning the structure of ownership, no OECD or World Bank standards exist in the area. One can alternatively exploit measures of effective ownership concentration or rely on indirect measures of legal environment (shareholders protection, for instance). Because my main focus is about capturing the overall stability of ownership, I rely on data measuring effective ownership concentration (OC indicator). Very few data are available for large scale cross-country analyses. A suitable indicator is provided by La Porta et al. [1998], [1999] and Djankov et al. [2006]. However, only one single observation in time is available: ${ }^{3}$ concentration is measured as the

\footnotetext{
${ }^{2}$ Those countries are: Australia, Austria, Belgium, Canada, Denmark, Finland, France, Germany, Ireland, Italy, Japan, Netherlands, Norway, Portugal, Spain, Sweden, United Kingdom, United States

${ }^{3}$ Kho et al. [2006] propose an indicator of ownership concentration based on Worldscope data, available for two points in time (1994 and 2004). However, the authors themselves
} 
"average percentage of common shares owned by the top three shareholders in the ten largest non-financial, privately-owned domestic firms in a given country. A firm is considered privately-owned if the State is not a known shareholder in it".

Finally, turning to regulation on labour markets (EPL indicator), this is captured through the time-series indicator provided by Amable, Demmou and Gatti [2007]. This measure is obtained by interpolating the standard OECD indicator, on the basis of information collected through the FRDB Social Reforms Database ${ }^{4}$. FRDB database provides detailed records about social reforms in European countries in the areas of employment protection legislation, over the period 1985-2005. The specific procedure used to construct the EPL series is fully described by Amable, Demmou and Gatti [2007].

Let us now have a first look at the data and, in particular, to the descriptive evidence about levels of regulation and concentration, as well as their effects on growth.

Figure 1 below presents EPL and OC indicators for all countries included in the sample (vertical and horizontal red lines represent sample mean of each variable). The average country values of EPL is depicted against the single available country values of ownership concentration. As the figure shows, countries in the sample are distributed across different levels of labour markets regulation and ownership concentration. However, a positive correlation appears between the two indicators of labour markets regulation and ownership concentration. The picture also highlights countries for which both OC and EPL are above (below) the sample mean value (sample means are indicated by brown lines). An important number of countries appear to be characterized by either high or low levels of both OC and EPL: as expected, Anglo-Saxon countries share low concentration and low regulation; while South European countries as well as Germany, Belgium and Austria feature high concentration and high regulation. However, several countries lie between these two groups, in particular North European countries as well as France, Ireland and Canada.

point to several weaknesses of these data, in particular the fact that Worldscope firms' population is very heterogenous (in size and composition) across countries and unstable over time (it has actually been increasing over time).

${ }^{4}$ The FRDB Social Reforms Database has been developed by the Fondazione Rodolfo Debenedetti (http://www.frdb.org). 


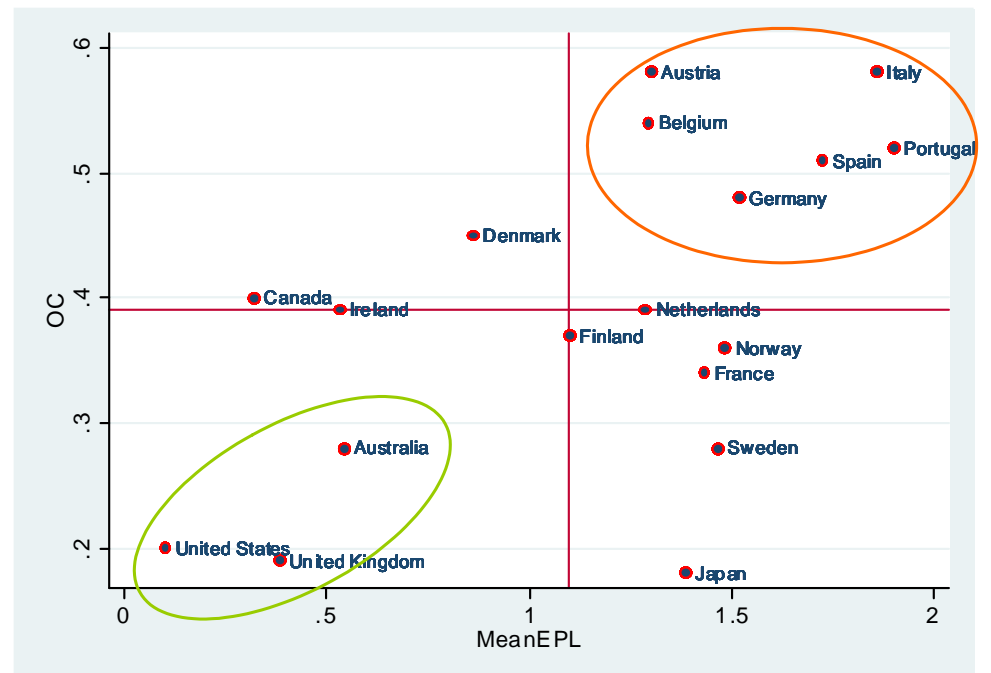

Figure 1. OC and EPL in sample countries

I now turn to the question of the relation between OC and GDP per employee growth. Figures 2 below allows to get a first impression about the effects of ownership concentration on growth. In this figure, average country growth rates of GDP per employee are drawn against OC. In the figure, I have highlighted countries experiencing average growth rates (over the whole period)) that are higher than the sample mean. As one can see, those countries are fairly distributed across different levels of concentration and regulation. In particular, there does not seem to be any clear negative relationship between concentration, regulation and growth. An important subset of countries (among which Germany and North European countries) have experienced fast growth rates in spite of high levels of concentration and/or regulation.

The descriptive evidence suggests that, within the sample and period considered, there is a positive relationship between levels of regulation and concentration. Moreover, fast growth does not appear to be the matter of low regulation/low concentration countries, but rather distributed across countries also showing high values of EPL and/or OC. To investigate more deeply the correlations between ownership, regulation and growth, let us now turn to the econometric analysis. 


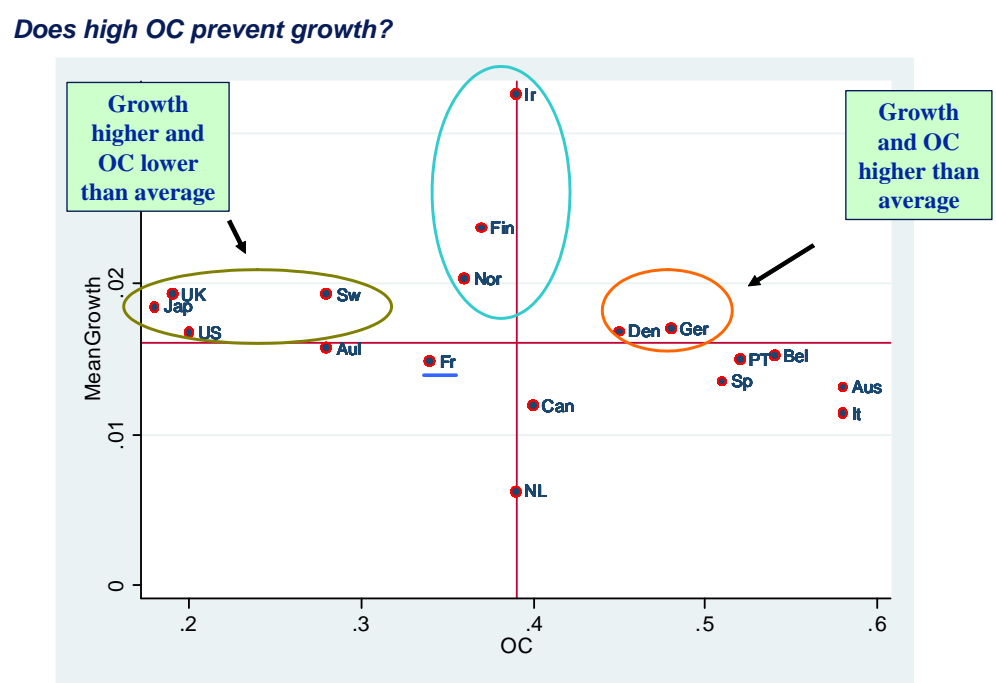

Figure 2

\section{Econometric analysis}

In this section, I develop an econometric analysis based on a standard growth equation. After presenting the empirical model to be tested, I briefly discuss the methodological issues related to estimations. Econometric results are then presented and their robustness checked in particular with respect to endogeneity issues.

\section{1 empirical model}

We have seen that recent contributions on the determinants of growth focus on the consequences of markets regulations on innovation: according to several authors, ${ }^{5}$ regulation affects innovation and growth differently according to a country's distance with respect to the technological (or production) frontier. This assumption implies that the macroeconomic consequences of regulation depend on contexts, i.e. on the level of development and wealth.

This assumption is certainly fair. However, a crucial question rises concerning the direction of the effects of regulation on growth, when countries

\footnotetext{
${ }^{5}$ Aghion [2006], Conway et al. [2006], Nicoletti and Scarpetta [2003], Acemoglu, Aghion and Zilibotti [2007].
} 
get closer to the frontier. The standard argument is that countries get more and more harmed by markets regulation as they get closer to the frontier. However, the theoretical issues and empirical evidence presented in the previous section suggest that countries may indeed profit more from stricter regulation and ownership concentration when they approach the technological frontier: stronger incentives to invest in up-to-date technologies, higher productive effort and implication by workers, a better perception of externalities linked to innovation could be crucial advantages to gain/consolidate a leadership position.

To tackle this issue, I estimate the joint effects of labour markets regulation and ownership concentration on growth, by using OECD data on 18 developed countries over the period 1980-2004. The estimated model includes regulation and ownership indicators, macroeconomic controls, the effects of externalities from leader countries as well as a measure of individual countries' distance with respect to the technological frontier (see, in particular, Nicoletti and Scarpetta, 2003):

$$
\begin{aligned}
\Delta \ln y_{i, t}= & \alpha_{i}+\phi_{1} \cdot \Delta \ln y_{F t}+\beta_{1} \cdot X_{i, t}+\beta_{2} \cdot Y_{i, t}+\beta_{3} \cdot E d u c_{i, t}+ \\
& +\zeta_{1} \cdot o c_{i, t}+\zeta_{2} \cdot e p l_{i, t}+\zeta_{3} \cdot o c_{i, t} \cdot e p l_{i, t}+ \\
& +\zeta_{4} \cdot d f_{i, t} \cdot o c_{i, t}+\zeta_{5} \cdot d f_{i, t} \cdot e p l_{i, t}+\epsilon_{i, t}
\end{aligned}
$$

$\alpha_{i}=$ individual country fixed effect, $y_{i, t}=$ GDP per employee, $\Delta \ln y_{i, t}=$ growth rate (difference between $\log \mathrm{GDP}$ at the end and at the beginning of period $t$ ), $y_{F t}=$ GDP per employee of frontier country at time $t$ (the frontier country is the country which has the highest GDP per employee level at period $t), d f_{i, t}=-\ln \frac{y_{i, t}}{y_{F t}}=$ country $i$ distance with respect to the frontier at time $t$ (the closer the country is to frontier the smaller the value of $d_{i, t}$ with $0 \leqq d f_{i, t} \leqq 1$ ). Moreover, $E d u c_{i, t}=$ a proxy for human capital in country $i$ at time $t, Y_{i, t}=$ vector of macroeconomic controls, $X_{i, t}=$ vector of markets regulation variables, $e p l_{i, t}=$ employment protection legislation, $o c_{i, t}=$ ownership concentration.

In order to properly estimate (1) one has to solve two methodological problems: first, how to treat slowly changing variables (such as indicators for regulation and ownership concentration) within a fixed effects model; second, how to appreciate the overall effects of variables included in interactions 
terms.

Concerning the first problem, a few variables included in the model (such as ownership concentration and product market regulation) are invariant or change very slowly. These variables capture features that characterize a single country - or a small subset of countries: they are thus very close to individual country effects. Plümper and Tröger [2007] propose a specific technique for analyzing the effect of time-invariant variables in fixed-effect models: the FEVD estimator. This procedure takes three steps: (i) estimate a fixed-effects model (ii) regress the unit effects on the time-invariant variables (iii) re-estimate the first stage including the error term of the second stage. The procedure amounts to extracting from the fixed effect the part of it that is explained by slowly changing variables. This allows to give more sense to fixed effects by explicitly modelling their institutional components. The FEVD estimator appears to be crucial in the present study because of the specificity of certain indicators, in particular OC wich has no time profile.

Turning to the second issue, the empirical model (1) includes three interaction terms allowing to capture the idea that the macroeconomic consequences of ownership structure depend on contexts. First, we have seen that the impact of ownership may vary in response to the degree of regulation on labour markets: this effect is apprehended through an interaction term between EPL and OC. Second, the consequences of regulation and ownership may also depend on the country's distance to the technological frontier; for this reason, I have included two interaction terms between EPL (respectively, OC) and countries' distance to frontier (DF). In the presence of interaction terms, the overall impact of OC and EPL on growth is obtained by computing the marginal effect conditional on specific values of the interacted variables (Braumeoller, 2004). From model (1) one has:

$$
\begin{aligned}
& \frac{\partial \Delta \ln y}{\partial o c}=\zeta_{1}+\zeta_{3} \cdot e p l+\zeta_{4} \cdot d f \\
& \frac{\partial \Delta \ln y}{\partial e p l}=\zeta_{2}+\zeta_{3} \cdot o c+\zeta_{5} \cdot d f
\end{aligned}
$$

Hence, the consequences of ownership concentration depend first, on the regulatory context (the level of EPL) and second, on the country distance to frontier (the value of $\mathrm{DF}$ ). The same reasoning applies to employment 
protection legislation. A specific procedure presented by Amable, Demmou and Gatti [2007] allows to evaluate the effects of each relevant variable for different levels of the interacted variables. This amounts to calculating the marginal effects of each relevant variable, as well as all statistics about the significance of those marginal effects.

\section{2 results}

I now turn to the analysis of GDP per employee's growth. My baseline model is (1) which includes regulation and ownership indicators, macroeconomic controls and a proxy for human capital (education). My main focus is on the effects of ownership concentration and employment protection legislation. However, I also include institutional variables controlling for other characteristics of product market structure, such as state intervention (PMR-SI) and the extent of regulation in key-service sectors (REGREFF).

I run regressions using two alternative estimators: the FEVD estimator, which yields efficient estimations of slowly-changing variables, and two-stage instrumental variable estimator (XTIVREG2 procedure) which allows to control for a possible endogeneity of regressors. Invariant variables in FEVD regressions are: product market regulation-state intervention (PMR-SI) and ownership concentration (OC).

A growing literature suggests that institutional devices (such as ownership concentration and markets regulation) may be endogenous and depend on several concurring processes: feedback from economic performance, political pressures, legal constraints, path dependence (Amable and Gatti, 2004; Cusack, Iversen and Soskice, 2007; Gatti and Glyn, 2006; Pagano and Volpin, 2005; Persson, Roland and Tabellini, 2007). From an empirical point of view, the question is how to satisfactorily account for endogeneity. A few recent papers tackle the issue of endogeneity with longitudinal data for developed and/or developing countries (Amable, Gatti and Schumacher [2006]; La Porta et al. 1998, 1999; Djankov, La Porta, López-de-Silane and Shleifer 2006) by making use of an instrumental variables (IV) approach. I adopt the same procedure in this paper and consider the following variables as endogenous: Distance to frontier, EPL*Distance to frontier, OC*Distance to frontier, EPL, OC, EPL*OC. The selected instruments for IV estimations are: lagged endogenous variables, age structure of the population (proportion of elderly people), unions' bargaining power (union density rate), Rae's 
index of fractionalization of party system, incidence of protest votes.

Results presented in table below show similar coefficients for the two alternative estimation procedures. However, it appears to be impossible to properly account for time-invariant variables (such as OC and PMR-SI) with the instrumental variable procedure. The $\mathrm{OC}$ variable automatically drops out of regressions (and does not show up in results below), because it confounds with unit fixed effects in first-stage regressions. On the contrary, the FEVD procedure allows to cope with this problem by extracting, from fixed effects, the component that is explained by slowly-changing indicators. Hence, this procedure appears as more appropriate to estimate (1).

As one can see from Table 1, human capital contributes to speed up GDP per employees' growth, while distance to frontier appears to play mostly through interaction terms. Concerning EPL, OC and PMR-SI all prove significant in FEVD regressions, while REGREFF is never significant. State intervention yields a positive effect, which can be explained by the role of state-owned companies in fostering innovation in crucial sectors of the economy. As suggested in existing economic literature (quoted in Sections above), the direct effect of EPL and OC on growth is negative.

However, additional information about the overall effects of EPL and OC needs to be gathered from the analysis of the interaction terms. In fact, all interaction terms are significant under FEVD and XTIVREG2 regressions. As one can see, the interaction between EPL and OC has a positive and significant impact on growth: stronger employment protection (respectively, ownership concentration) favors growth in contexts where OC (respectively, EPL) levels are higher. This counters the direct negative effects of increased regulation and concentration. Moreover, results about the two interaction terms between "distance to frontier", on the one hand, and EPL or OC, on the other hand, prove that the overall impact of EPL and OC on growth depends on the country position with respect to the frontier. Given the signs of the estimated coefficients, the negative impact of $\mathrm{OC}$ on growth becomes smaller when approaching the frontier. Concerning the effect of EPL, the positive sign of the interaction term shows that the direct negative impact of EPL is considerably reduced for countries that are far away from the frontier. 
Table 1

\begin{tabular}{|c|c|c|}
\hline DlogGDP per employee & [1] & [2] \\
\hline DlogFrontier & $\begin{array}{l}0.302^{* * *} \\
(0.108)\end{array}$ & $\begin{array}{l}0.297^{* * *} \\
(0.092)\end{array}$ \\
\hline Distance to frontier & $\begin{array}{l}0.119 \\
(0.086)\end{array}$ & $\begin{array}{l}0.206^{*} \\
(0.128)\end{array}$ \\
\hline Effective real exchange rate & $\begin{array}{l}-0.024^{*} \\
(0.014)\end{array}$ & $\begin{array}{l}-0.031^{\star *} \\
(0.012)\end{array}$ \\
\hline Education & $\begin{array}{l}0.061^{\star \star *} \\
(0.015)\end{array}$ & $\begin{array}{l}0.078^{* * *} \\
(0.023)\end{array}$ \\
\hline EPL*distance to frontier & $\begin{array}{l}0.114^{\star \star \star} \\
(0.032)\end{array}$ & $\begin{array}{l}0.188^{* \star *} \\
(0.042)\end{array}$ \\
\hline $\mathrm{OC}^{*}$ distance to frontier & $\begin{array}{l}-0.409^{*} \\
(0.218)\end{array}$ & $\begin{array}{l}-0.737^{* *} \\
(0.349)\end{array}$ \\
\hline EPL & $\begin{array}{l}-0.075^{\star * *} \\
(0.026)\end{array}$ & $\begin{array}{l}-0.132^{*} \\
(0.069)\end{array}$ \\
\hline $\mathrm{EPL}{ }^{\star} \mathrm{OC}$ & $\begin{array}{l}0.154^{\star \star \star} \\
(0.053)\end{array}$ & $\begin{array}{l}0.272^{*} \\
(0.148)\end{array}$ \\
\hline REGREFF & $\begin{array}{l}0.000 \\
(0.001)\end{array}$ & $\begin{array}{l}0.00 \\
(0.00)\end{array}$ \\
\hline $\mathrm{OC}$ & $\begin{array}{l}-0.039^{* \star \star} \\
(0.007)\end{array}$ & \\
\hline PMR SI & $\begin{array}{l}0.011^{\star \star *} \\
(0.001)\end{array}$ & $\begin{array}{l}0.0054 \\
(0.004)\end{array}$ \\
\hline eta & $\begin{array}{l}1.000^{* * \star} \\
(0.045)\end{array}$ & \\
\hline Estimator & $\begin{array}{l}\text { XTFEVD } \\
\text { pcse option }\end{array}$ & $\begin{array}{l}\text { XTIVREG2 } \\
\text { gmm option }\end{array}$ \\
\hline $\begin{array}{l}\text { Time/country dummies } \\
\text { Number of Obs }\end{array}$ & $\begin{array}{l}\text { Yes } \\
410\end{array}$ & $\begin{array}{l}\text { Yes } \\
380\end{array}$ \\
\hline
\end{tabular}

Note: Standard errors in parentheses

${ }^{*} p<0.10,{ }^{* *} p<0.05,{ }^{* * *} p<0.01$

Summary test statistics for IV regression Anderson Rubin test Stoch Wright test

Hansen J statistic

Endogeneity test

$\begin{array}{ll}\mathrm{F}(9,343)=6.28 & \mathrm{P} \text {-value }<1 \% \\ \text { Chi-sq }(9)=41.12 & \mathrm{P} \text {-value }<1 \% \\ 5.442 & \mathrm{P} \text {-value }>10 \% \\ 17.962 & \mathrm{P} \text {-value }<5 \%\end{array}$

A more detailed evaluation of the direct/indirect effects of OC and EPL is reported in the Appendix (Table 2) where I present estimations for all marginal coefficients. The main implications of these estimation results are presented in the following section. 


\section{Evaluating the impact of ownership concentra- tion}

As shown in Table 1 (first column), the FEVD procedure provides robust estimations for time-invariant indicators (OC in particular). Based on such estimations, it appears that the impact of variable OC on growth depends on contexts, i.e. on existing regulation and on country "distance to frontier".

More precisely, Table 2 (Appendix) gives all marginal coefficients for OC (and EPL). This shows that the overall OC coefficients are negative for low levels of EPL, and become positive for higher levels of EPL (if country

"distance to frontier" ranges from average to very small). Hence, ownership concentration favors growth when countries get closer to frontier provided that those countries feature (at least) average levels of employment protection legislation. The effect becomes stronger the closer a country gets to frontier.

These results provide an answer to the crucial questions raised in this paper. First, stronger ownership concentration is not necessarily bad for growth. Second, leader countries benefit more from ownership concentration in the presence of a strong regulation on the labour market. Hence, econometric results provide some support to the theoretical arguments suggesting a positive impact of concentration on growth, provided that concentrated ownership is embedded into a suitable context (i.e. a highly regulated environment). I will explore more deeply the issue in Section below.

\section{1 overall effects of changes in concentration}

I rely hereafter on estimated marginal coefficients reported in Table 2 (Appendix). These coefficients can be used to build impact coefficients for variable OC. Impact coefficients measure the growth points gained/lost following a certain increase in ownership concentration. I calculate impact coefficients for different reference values of context variables: levels of regulation and country distance to frontier (DF). In particular, I consider three groups of countries: 'leaders' for which variable DF goes from min $D F$ up to meanDF minus one sdDF; 'average countries' for which variable DF is comprised between meanDF minus one sdDF and meanDF plus one sdDF; and finally, 'laggards' for which variable DF ranges between max $D F$ and meanDF plus one sdDF. 
Let me now turn to the analysis of the overall impact of ownership concentration on growth. By using coefficients presented in Table 2, I calculate the growth points gained/lost following a 5 points increase in ownership concentration (ex. from $20 \%$ to $25 \%$ of concentration), provided that estimated coefficients are statistically significant. These gains/losses are evaluated for minimum to maximum country distance to frontier. Results are presented in Figure 3 below.

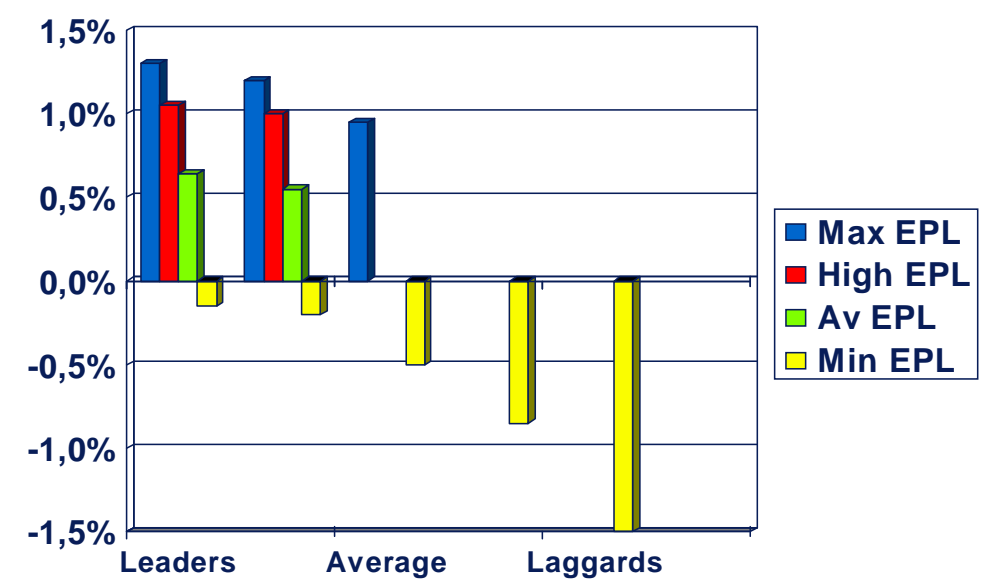

Figure 3. Growth points gained/lost following a 5 points increase in $\mathrm{OC}$

The picture shows that, for laggards and average countries, the overall impact of a 5 point increase in ownership concentration is significant and negative with low EPL levels, while not significant when EPL takes average to maximum levels. For leader countries, it appears that the impact of increased ownership concentration becomes significant and positive when employment regulation ranges from average to maximum levels; in this case, the overall impact of a 5 points increase in ownership concentration is relatively important for growth as it delivers additional 1-1,3 points of GDP per employee growth.

One might want to know how would sample countries be affected by such an increase in ownership concentration. Figure 4 below shows that countries would respond differently as a consequence of a change in ownership 
structure. If one focuses on countries that are relatively close to the frontier, it appears that Anglo-Saxon countries (and in particular the US and Canada) lie in an area where one can expect negative effects from increased OC because of the very low levels of EPL; on the other hand, many European countries actually lie in an area where they would actually benefit from such increase thanks to the high levels of regulation. This result calls for futher checks; I will therefore explore more deeply the consequences of reforms in ownership and regulation, in the following Section.

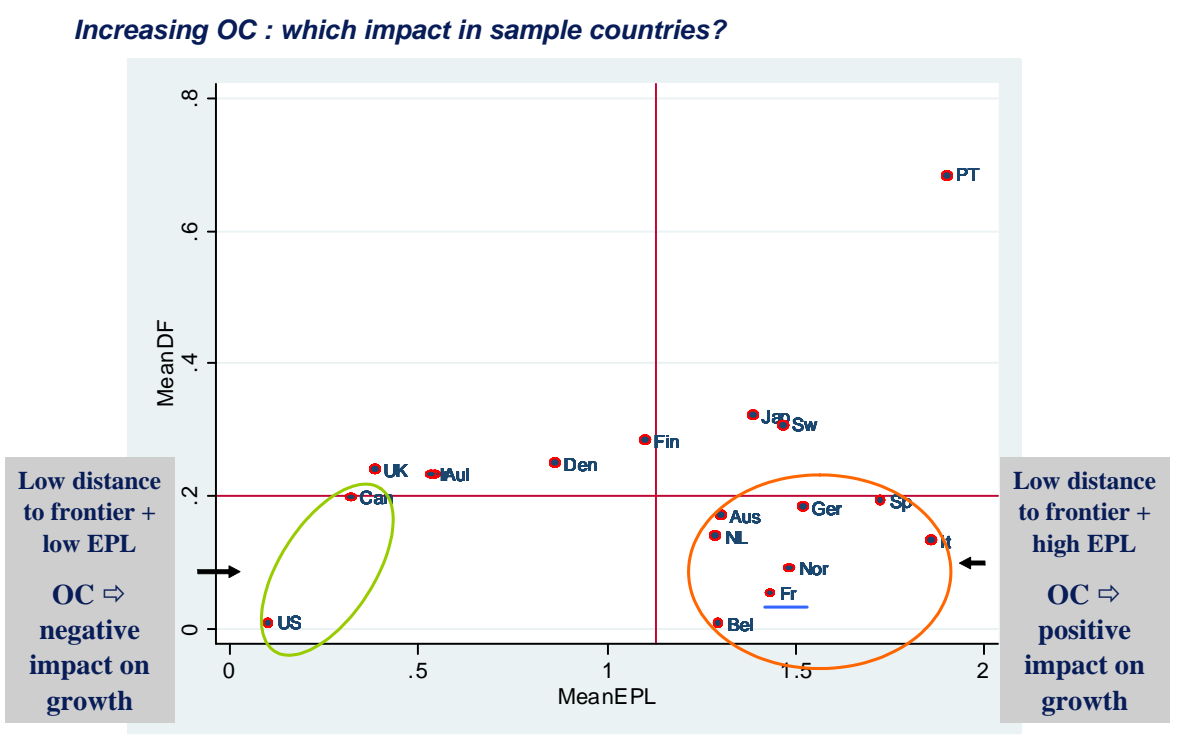

Figure 4

\section{2 policy scenarios}

In this Section I present simulations of GDP per employee's growth, based on estimated regression coefficients presented in Table 1 (column [1], FEVD procedure). Econometric results have provided some support to the idea that changes in ownership structure are likely to produce different results according to contexts, i.e. according to the prevailing level of labour market regulation and to country distance with respect to the frontier. Hence, simulations presented below aim to shade some light on the consequences, for all sample countries, of changes in selected variables, namely ownership concentration and employment regulation. 
In particular, four policy scenarios are simulated. First, I run a simulation exploring a situation where all countries would have selected levels of $\mathrm{OC}$ and EPL that are lower than actual ones by one standard deviation. The consequences of this change are shown in Figure 5. As one can see, this kind of reform would have benefited a few countries in the sample: the UK, the US, Ireland, Canada and Australia (plus Japan), i.e. primarily Anglo-Saxon low regulation countries. All other countries, and in particular European countries, take no advantage, and even experience lower growth, following such reform.

Second, I simulate the alternative situation where countries' policy choice would have been to implement levels of both OC and EPL that are higher than actual ones by one standard deviation. This change is shown to be potentially beneficial for all countries except the US and the UK (see Figure 6 below). Hence, a progressive increase in regulation and ownership concentration appears as a more suitable policy choice for continental European countries, as compared to the alternative deregulation policy.

Finally, two more simulations are run to test the alternative scenarios where EPL and OC would be put equal to their maximum or minimum sample values. This exercise allows to tentatively evaluate the long-run implications of reforms aiming at radically changing labour regulation and ownership structure. The simulations show the "provocative" result that selecting the highest sample values for OC and EPL would have indeed always been the best growth-oriented policy for all sample countries (see Figure 7 below).

\section{Conclusion}

This paper has investigated the impact of ownership structure on GDP per employee growth from a macroeconomic point of view. Contrary to common wisdom, the theoretical arguments presented in the paper suggest that concentrated ownership can in some cases favor growth. In fact, concentrated ownership tends to increase ownership stability thus fostering long term relationships with crucial stakeholders. In developed countries where (labour) markets are highly regulated, ownership stability can yield increased incentives to undertake firm-specific investments. These investments favor productivity growth in different sectors of the economy, and can be crucial 
to achieve and/or maintain technological leadership.

The main contribution of the paper is empirical. I investigated the impact of ownership concentration on growth for a sample of 18 OECD countries over the period 1980 to 2004. The econometric analysis shows that the effects of ownership concentration indeed depend on contexts, i.e. on the regulatory environment and on the country distance to the frontier. In fact, more concentrated ownership can yield positive effects on growth (in particular for leader countries) provided that labour market regulation is sufficiently tight. In the absence of employment regulation, the logic of financial markets discipline applies and dispersed ownership appears as more favorable for growth.

Finally, the paper has provided some hints about the possible effects of changes in ownership concentration and regulation. Based on econometric results, impact coefficients have been presented allowing to evaluate the growth points gained/lost following a given change in ownership concentration. This exercise reveals that a reform in the domain of ownership structure can yield sizeable effects in terms of growth. More important, these effects are unequally distributed across countries: Anglo-Saxon countries would take more advantage of deregulation (i.e. increased dispersion of ownership in a context of deregulated labour markets) while European countries would benefit more from increased concentration of ownership in a context of reinforced regulation. 
Simulation with OC and EPL equal to real values less 1sd (GDPgrowth_LOW_OC_EPL)
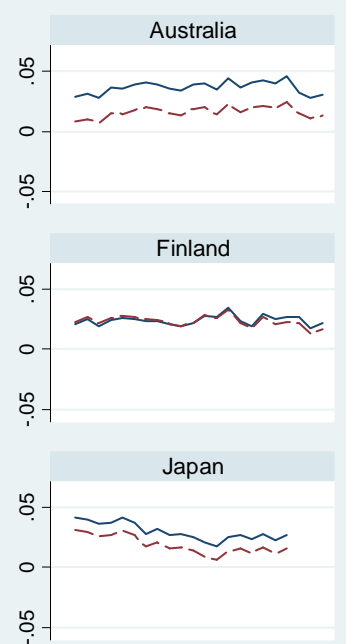

Sweden

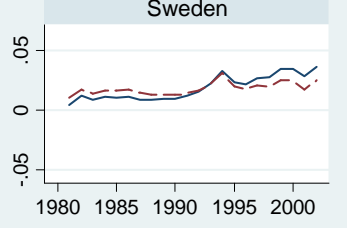

Austria

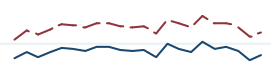

France

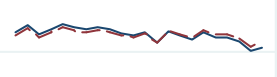

Netherlands

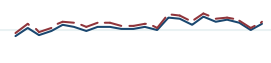

United Kingdom

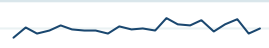

ヘーーーーハヘール

$\begin{array}{llll}1980 & 1985 & 1990 & 1995 \quad 2000\end{array}$
Belgium

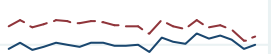

Germany

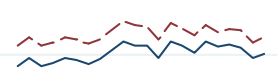

Norway
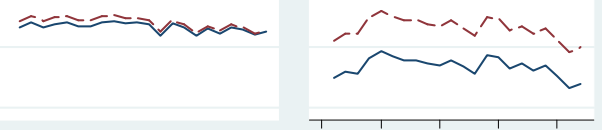

$1980 \quad 1985 \quad 1990 \quad 1995 \quad 2000$
Denmark

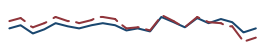

Italy

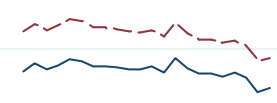

Spain

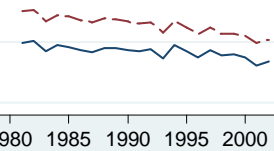

United States

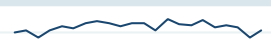

- - - - -

$\begin{array}{lllll}1980 & 1985 & 1990 & 1995 & 2000\end{array}$

time

\section{GDPgrowth_LOW_OC_EPL}

\section{Linear prediction}

Graphs by country

Figure 5 
Simulation with OC and EPL equal to real values plus 1sd (GDPgrowth_HIGH_OC_EPL)
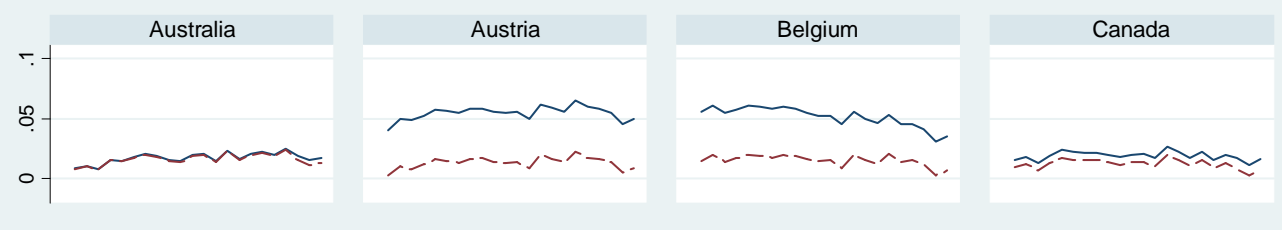

Denmark
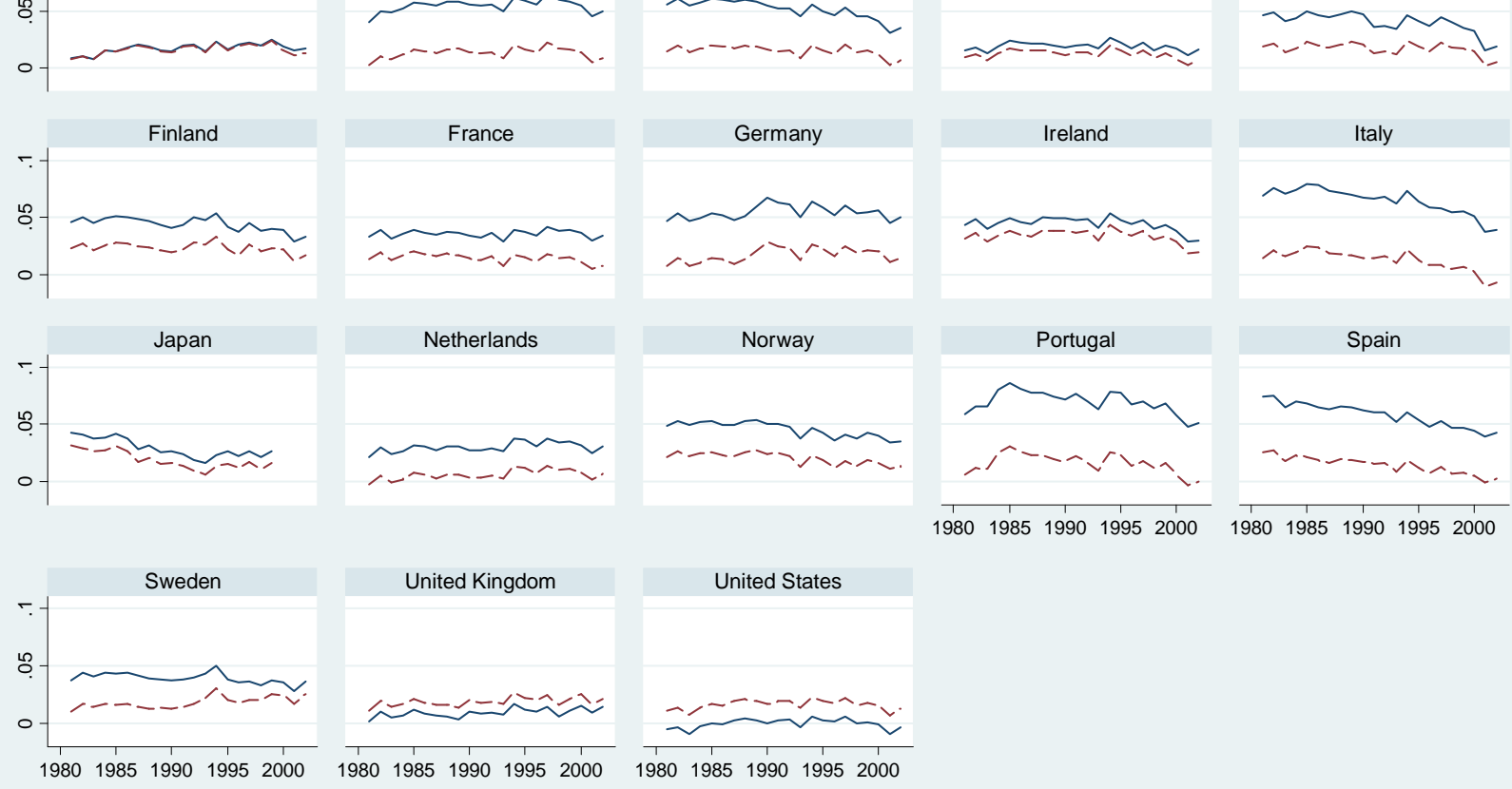

time

\section{GDPgrowth_HIGH_OC_EPL}

\section{Graphs by country}

Figure 6 
Simulations with OC and EPL equal to max and min sample values (GDPgrowth_Max_OC_EPL and GDPgrowth_Min_OC_EPL)
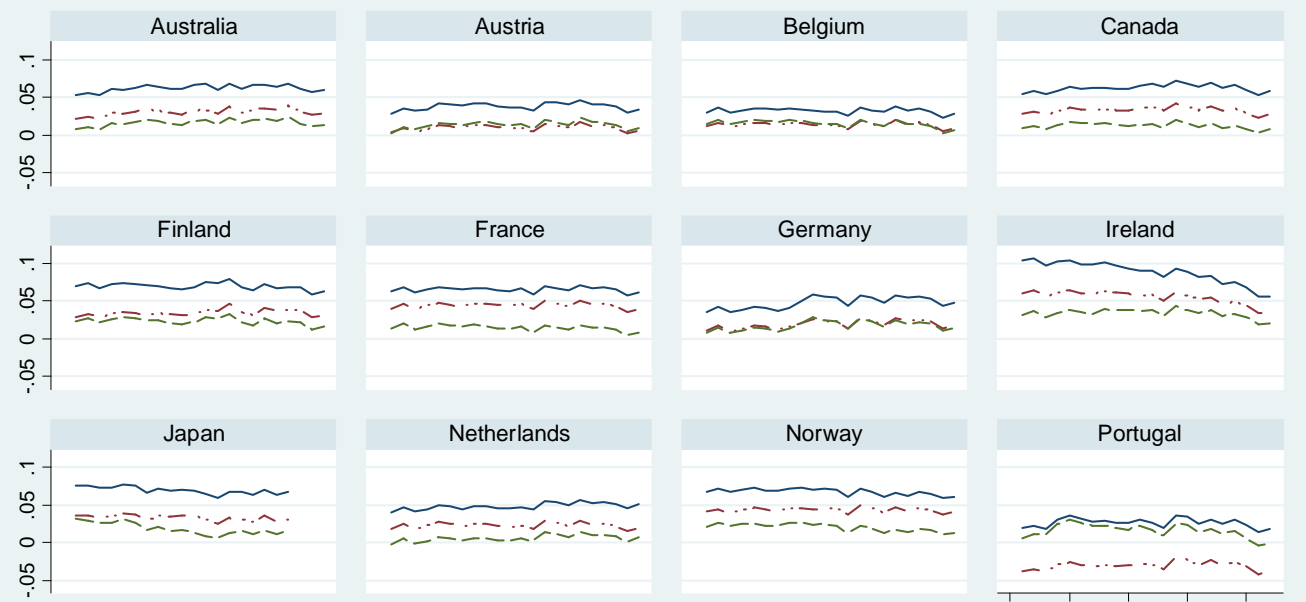

Denmark
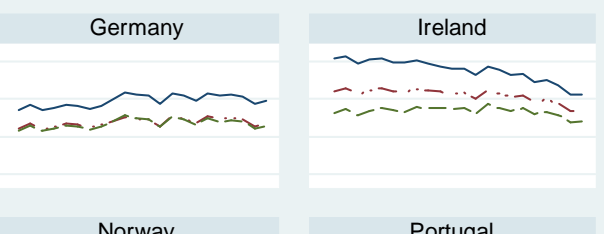

Italy
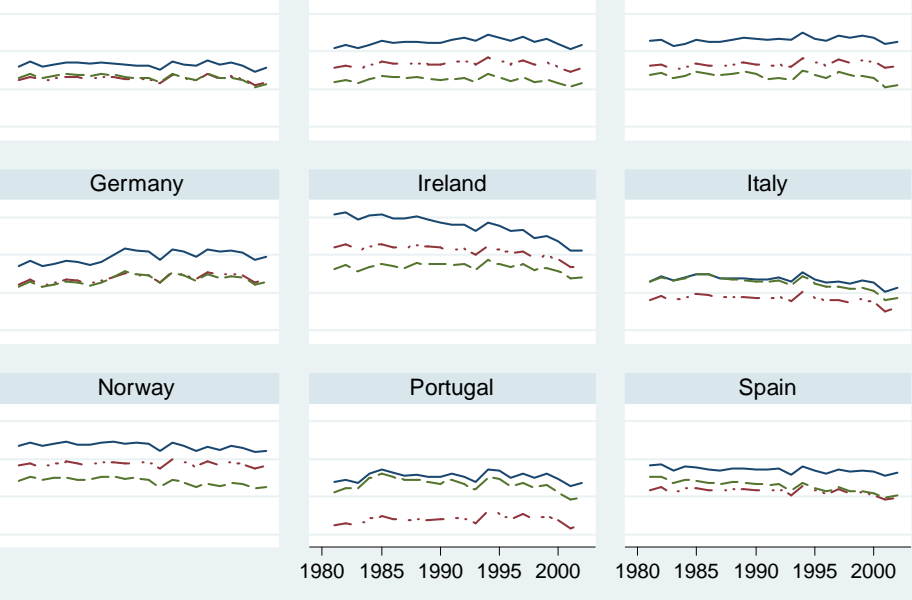

Spain

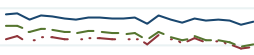

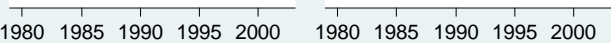

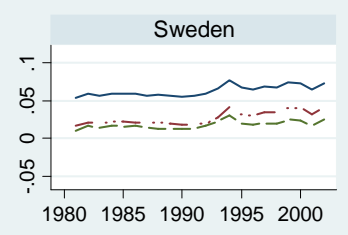

United Kingdom

United States
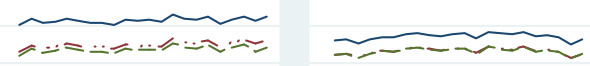

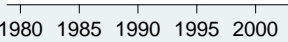

time

\section{GDPgrowth_Max_OC_EPL Linear prediction}

Graphs by country

Figure 7 


\section{Appendix}

\section{1 data and sources}

Product markets regulation is measured through standard OECD indicators such as PMR and REGREFF: PMR is a global regulation indicators (only two observations are available), while REGREFF is a time-series indicator assessing the extent of regulation in key service sectors (such as gas, electricity, transports, etc.). OECD also provide a decomposition of PMR according to fields of regulation: state intervention, barriers to firms' creation, trade barriers. The extent of state intervention is a potentially crucial variable in my analysis because it also captures an important aspect of companies' ownership structure.

Macroeconomic control (such as real effective exchange rate) are drawn from the OECD annual dataset. Education is measured as the proportion of enrolled students out of corresponding age-class population (OECD data). Population data, such as the share of the population aged 65 years and older (elderly population), are obtained from OECD.

In order to run instrumental variable technique, I rely on several political indicators from the Comparative Political Data Set (Armingeon et al. 2005): the Rae's index of fractionalization of the political party system, the share of 'protest' votes (defined as the sum of votes for radical parties and abstention), a dummy for corporatist countries. Moreover, few data are obtained from M. Pagano's online database (www.csef.it/people/pagano_data.htm), in particular dummy variables for proportional voting systems as well as for countries' legal origins (German, common and Scandinavian). Finally, I consider a annual indicator of left/right ideological positioning of governments elaborated and proposed by Amable, Gatti and Schumacher [2006].

\section{2 marginal coefficients}

To assess the overall impact of EPL and OC, I calculate marginal effects and their significance conditional to five alternative values of the relevant variables: minimum and maximum levels, mean value and mean plus/minus one standard deviation. Results are reported below separately for the marginal effect of EPL and OC. 


\section{Table 2}

\begin{tabular}{|c|c|c|c|c|c|}
\hline & $\begin{array}{l}\text { Min distance } \\
\text { to frontier }\end{array}$ & $\begin{array}{l}\text { Low distance } \\
\text { to frontier }\end{array}$ & $\begin{array}{l}\text { Average distance } \\
\text { to frontier }\end{array}$ & $\begin{array}{l}\text { High distance } \\
\text { to frontier }\end{array}$ & $\begin{array}{l}\text { Max distance } \\
\text { to frontier }\end{array}$ \\
\hline \multicolumn{6}{|c|}{ Marginal effect of EPL } \\
\hline Min OC & $\begin{array}{l}-0.045^{\star * \star} \\
(0.017)\end{array}$ & $\begin{array}{l}-0.042^{* *} \\
(0.016)\end{array}$ & $\begin{array}{l}-0.024^{*} \\
(0.013)\end{array}$ & $\begin{array}{l}-0.006 \\
(0.011)\end{array}$ & $\begin{array}{l}0.040^{* * *} \\
(0.015)\end{array}$ \\
\hline Mean OC less 1sd & $\begin{array}{l}-0.031^{\star *} \\
(0.013)\end{array}$ & $\begin{array}{l}-0.028^{\star \star} \\
(0.012)\end{array}$ & $\begin{array}{l}-0.010 \\
(0.009)\end{array}$ & $\begin{array}{l}0.007 \\
(0.008)\end{array}$ & $\begin{array}{l}0.054^{\star \star *} \\
(0.016)\end{array}$ \\
\hline Mean OC & $\begin{array}{l}-0.012 \\
(0.008)\end{array}$ & $\begin{array}{l}-0.009 \\
(0.008)\end{array}$ & $\begin{array}{l}0.009 \\
(0.006)\end{array}$ & $\begin{array}{l}0.026^{\star \star \star} \\
(0.008)\end{array}$ & $\begin{array}{l}0.073^{\star \star \star} \\
(0.020)\end{array}$ \\
\hline Mean OC plus 1sd & $\begin{array}{l}0.007 \\
(0.008)\end{array}$ & $\begin{array}{l}0.011 \\
(0.008)\end{array}$ & $\begin{array}{l}0.028^{\star \star \star} \\
(0.009)\end{array}$ & $\begin{array}{l}0.046^{* * *} \\
(0.013)\end{array}$ & $\begin{array}{l}0.092^{* * *} \\
(0.025)\end{array}$ \\
\hline Max OC & $\begin{array}{l}0.017^{\star} \\
(0.009)\end{array}$ & $\begin{array}{l}0.020^{\star *} \\
(0.010)\end{array}$ & $\begin{array}{l}0.038^{* * *} \\
(0.012)\end{array}$ & $\begin{array}{l}0.055^{\star * \star} \\
(0.016)\end{array}$ & $\begin{array}{l}0.102^{* * *} \\
(0.027)\end{array}$ \\
\hline
\end{tabular}

Note: Standard errors in parentheses

${ }^{*} p<0.10,{ }^{* \star} p<0.05,{ }^{* * *} p<0.01$

Marginal effect of OC

\begin{tabular}{|c|c|c|c|c|c|}
\hline Min EPL & $\begin{array}{l}-0.031^{\star * *} \\
(0.010)\end{array}$ & $\begin{array}{l}-0.044^{\star \star *} \\
(0.014)\end{array}$ & $\begin{array}{l}-0.107^{\star *} \\
(0.045)\end{array}$ & $\begin{array}{l}-0.170^{\star *} \\
(0.078)\end{array}$ & $\begin{array}{l}-0.338^{\star *} \\
(0.167)\end{array}$ \\
\hline Mean EPL less 1sd & $\begin{array}{l}0.042 \\
(0.032)\end{array}$ & $\begin{array}{l}0.030 \\
(0.033)\end{array}$ & $\begin{array}{l}-0.033 \\
(0.052)\end{array}$ & $\begin{array}{l}-0.097 \\
(0.081)\end{array}$ & $\begin{array}{l}-0.264 \\
(0.166)\end{array}$ \\
\hline Mean EPL & $\begin{array}{l}0.128^{\star \star} \\
(0.061)\end{array}$ & $\begin{array}{l}0.115^{\star} \\
(0.061)\end{array}$ & $\begin{array}{l}0.052 \\
(0.071)\end{array}$ & $\begin{array}{l}-0.011 \\
(0.093)\end{array}$ & $\begin{array}{l}-0.179 \\
(0.171)\end{array}$ \\
\hline Mean EPL plus 1sd & $\begin{array}{l}0.213^{\star *} \\
(0.090)\end{array}$ & $\begin{array}{l}0.200^{\star *} \\
(0.090)\end{array}$ & $\begin{array}{l}0.137 \\
(0.096)\end{array}$ & $\begin{array}{l}0.074 \\
(0.112)\end{array}$ & $\begin{array}{l}-0.093 \\
(0.180)\end{array}$ \\
\hline Max EPL & $\begin{array}{l}0.267^{\star *} \\
(0.109)\end{array}$ & $\begin{array}{l}0.255^{\star *} \\
(0.109)\end{array}$ & $\begin{array}{l}0.191^{*} \\
(0.113)\end{array}$ & $\begin{array}{l}0.128 \\
(0.126)\end{array}$ & $\begin{array}{l}-0.039 \\
(0.188)\end{array}$ \\
\hline
\end{tabular}

Note: Standard errors in parentheses

${ }^{*} p<0.10,{ }^{* *} p<0.05,{ }^{* * *} p<0.01$ 


\section{References}

[1] Acemoglu, Daron, Philippe Aghion and Fabrizio Zilibotti (2007) "Distance to Frontier, Selection and Economic Growth", Journal of the European Economic Association.

[2] Aghion P. (2003) Empirical estimates of the relationship between product market competition and innovation. In J.P. Touffut (ed.) Institutions, Innovation and Growth, Selected Economic Papers, pp. 142-169. Cheltenham: Edward Elgar.

[3] Aghion, P. (2006) A Primer on Innovation and Growth. BRUEGEL Policy Brief Issue 2006/06.

[4] Aghion P., N. Bloom, R. Blundell, R. Griffith and P. Howitt (2005) "Competition and Innovation: An Inverted U Relationship" Quarterly Journal of Economics, May 2005a, pp. 701-728.

[5] Aghion, P. and Howitt, P. (1992). A Model of Growth Through Creative Destruction. Econometrica, 60(2), 323-351.

[6] Aguilera, R.V. \& G. Jackson (2003): The Cross-National Diversity of Corporate Governance: Dimensions and Determinants. Academy of Management Review, 28: 447-465

[7] Amable B., L. Demmou and D. Gatti [2007] Employment Performance and Institutions: New Answers to an Old Question. IZA Discussion Paper No. 2731.

[8] Amable B., L. Demmou and I. Ledezma [2007] Competition, Innovation and Distance to frontier. mimeo, CEPREMAP.

[9] Amable B. and D. Gatti [2004] The Political Economy of Job Protection and Income Redistribution IZA Discussion Paper No. 1404.

[10] Amable B., D. Gatti and J. Schumacher (2006) Welfare state retrenchment: the partisan effect revisited, Oxford Review of Economic Policy, $22: 3$, autumn

[11] Amable B. and B. Hancké (2001) Innovation and Industrial Renewal in France in Comparative Perspective. Industry and Innovation 8(2), 113-133. 
[12] Armingeon, Klaus, Philipp Leimgruber, Michelle Beyeler and Sarah Menegale (2005). Comparative Political Data Set 1960-2003, Institute of Political Science, University of Berne.

[13] Barker R. and David Rueda [2007] The Labor Market Determinants of Corporate Governance Reform, CLPE Research Paper 5/2007, Vol. 03 No. 03.

[14] Becht, Marco and Colin Mayer (2001), "Corporate Control in Europe", in The World's New Financial Landscape : Challenges for Economic Policy, Mohr-Siebeck, Tübingen.

[15] Blair M. [2003] Shareholder Value, Corporate Governance, and Corporate Performance in Peter K. Cornelius and Bruce Kogut, eds., Corporate Governance and Capital Flows in a Global Economy (Oxford University Press, 2003, 53-82)

[16] Braumoeller, Bear F. 2004. "Hypothesis Testing and Multiplicative Interaction Terms". International Organization, Vol. 58, No. 4, pp. 807820 .

[17] Conway P., V. Janod and G. Nicoletti (2005), "Product Market Regulation in OECD Countries, 1998 to 2003". OECD Economics Department Working Paper, No 419

[18] Conway, P. and G. Nicoletti 2006. " Product Market regulation in the Non-Manufacturing Sector of OECD Countries: Measurements and Highlights". OECD Economics Department Working Paper No. 530.

[19] Conway P., D. de Rosa, G. Nicoletti and F. Steiner (2006) "Regulation, Competition, and Productivity Convergence. Economics Department Working Papers No. 509, Paris: OECD.

[20] Cusack T., Iversen T. and D. Soskice " Economic Interests and the Origins of Electoral Systems." American Political Science Review 101, August 2007

[21] Djankov S., La Porta R., Florencio López-de-Silane and Andrei Shleifer [2006] The Law and Economics of Self-Dealing", Journal of Financial Economics, November. 
[22] Deakin, S., Hobbs, R., Konzelmann, S. and Wilkinson, F. (2002) 'Partnership, ownership and control: the impact of corporate governance on employment relations', Employee Relations, 24(3): 335-352.

[23] Faccio, Mara and Larry H.P. Lang. 2002. "The Ultimate Ownership in Western European Corporations," Journal of Financial Economics 65:3, pp. 365-395.

[24] Friedrich, Robert J. 1982. "In defence of multiplicative terms in multiple regression equations", American Journal of Political Science, Vol. 26, No.4, pp. 797-833.

[25] Gatti D. [2000] Unemployment and Innovation Patterns: the critical role of coordination, Industrial and Corporate Change, 9:3

[26] Gatti D. and A. Glyn (Eds.) [2006] Fiscal Restraint and the Welfare State, numéro spécial de la Oxford Review of Economic Policy, 22:3, autumn, Oxford University Press, Oxford

[27] Gatti D. and A. Glyn (2006) Welfare States in Hard Times, Oxford Review of Economic Policy, 22:3, autumn

[28] Geroski, P. (1995) Market Structure, Corporate Performance and Innovative Activity, Oxford: Oxford University Press

[29] Gugler K., Dennis C. Mueller, and B. Burcin Yurtoglu [2004], Corporate Governance and Globalization, Oxf Rev Econ Policy 2004 20: 129-156

[30] Kho Bong-Chan, René M. Stulz, Francis E. Warnock [2006] Financial Globalization, Governance, and the Evolution of the Home Bias, NBER Working Paper No. 12389

[31] La Porta, R., F. Lopez-De-Silanes, and A. Shleifer. (1999). "Corporate Ownership Around the World." Journal of Finance 54 (2):471-518.

[32] La Porta, Rafael , Florencio Lopez-de-Silanes, Andrei Shleifer, and Robert W. Vishny. (1998). "Law and Finance." Journal of Political Economy 106 (4):1113-55.

[33] Morck, Wolfenzon and Yeung [2005] Corporate Governance, Economic Entrenchment, and Growth, Journal of Economic Literature, Vol. 43, No. 3, September. 
[34] Nicoletti, G. and S. Scarpetta (2003), "Regulation, Productivity and Growth: OECD Evidence", Economic Policy, No. 36, pp. 9-72, April.

[35] Pagano, M., and P. F. Volpin. 2005. "The Political Economy of Corporate Governance." American Economic Review 95:1005-30.

[36] Persson T., Gerard Roland and Guido Tabellini (2007) "Electoral Rules and Government Spending in Parliamentary Democracies", Quarterly Journal of Political Science: Vol. 2:No 2, pp 155-188.

[37] Plümper Thomas and Vera Tröger 2007. "Efficient Estimation of Time Invariant and Rarely Changing Variables in Panel Data Analysis with Unit Effects", Political Analysis, Vol. 15, No. 2, pp. 124-139.

[38] Rebérioux A. (2002) European Style of Corporate Governance at the Crossroads: the Role of Worker Involvement, Journal of Common Market Studies, vol. 40, n 1 , pp. 111-134.

[39] Scruggs, Lyle 2004. Welfare State Entitlements Data Set: A Comparative Institutional Analysis of Eighteen Welfare States, Version 1.0.

[40] Shleifer, Andrei, and Robert Vishny. 1997. "A survey of Corporate Governance," Journal of Finance 52:2, pp. 737-783. 